\title{
地域高歯者における大腿骨頸部骨折予防装具の 装着率に関する基礎的研究
}

\begin{tabular}{|c|c|c|c|c|c|}
\hline 木 隆雄 ${ }^{1)}$ & 吉田 & 英世 ${ }^{1)}$ & 石崎 & 達郎 ${ }^{1)}$ & 湯川 \\
\hline 渡辺修一郎 ${ }^{2)}$ & 熊谷 & 修皇 & 新開 & 省二 ${ }^{2)}$ & 柴田 \\
\hline 村 哲郎 ${ }^{3)}$ & 細井 & 孝之记 & 安村 & 誠司 ${ }^{4)}$ & 芳賀 \\
\hline
\end{tabular}

〈要 約〉 我が国の高齢化社会を背景として急増している大腿骨頸部骨折を予防する目的で，最近欧米で 開発され利用されている大腿骨頸部骨折予防装具について，その装着率や脱落理由などの基本的研究を行 なった。

対象となったのは秋田県山間部農村に住む在宅高齢者（70歳以上）で，過去 1 年間に転倒した経験を有す る女性20名である。この対象者にデンマーク製の硬質ポリプロピレン製パットの入った装具（9名）とフィ ンランド製の軟質強化ゴム製パットの入った装具（11名）の 2 種類を用いて，平成 9 年 9 月から平成 10 年 3 月まで 6 カ月間追跡調查を行なった.

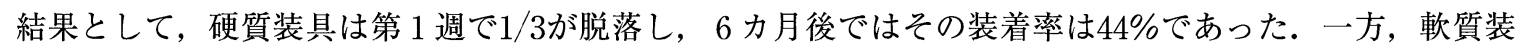
具の脱落率は比較的低く，最終的に $73 \%$ が装着を維持していた．脱落理由として，初期では「排尿時に間に 合わない」が多く，後期では寒い時の「下着の重ね着時に窮屈」などであった．装着継続群と脱落群との差 としては年歯や握力などがあげられたが，20名という少ない人数では明確な差異は抽出しえなかった.

今回の研究から，予防装具は最初に充分な説明と動機付けの得られることが重要であり，その後のより細 かな指導と動機を維持するならば（硬質，軟質を問わず）比較的高い装着率を維持することが可能であり， 高齢者の転倒による大腿骨頸部骨折を予防することが充分可能であると考えられた.

Key words : 大腿骨頸部骨折予防装具, 地域在宅高齢者, 装着率, 転倒, 脱落理由

（日老医誌 $1999 ； 36 ： 40-44 ）$

\section{1. 緒 言}

大腿骨頸部骨折の $90 \%$ は転倒によって生ずるとされ る ${ }^{1)}$ また高齢期における転倒は単に骨折のみならず, その後の転倒の恐怖心から ADL（日常生活動作能力）を 低下させる可能性も少なくなく，転倒は今後の我が国で の高齢者の特有の病態あるいは老人性症候群の一つとし て重大な関心を払わねばならない状況になってきてい る.

最近，地域の在宅高齢者を対象とし，全国的規模で面 接聞き取り調查を主体として調查方法，調查項目をほぼ 標準化した 1 年間における転倒の実態報告がなされてい

1) T. Suzuki, H. Yoshida, T. Ishizaki, H. Yukawa : 東京 都老人総合研究所疫学部門

2) S. Watanabe, S. Kumagai, S. Shinkai, H. Shibata : 東 京都老人総合研究所地域保健部門

3） T. Nakamura, T. Hosoi：東京都老人医療センター内 分泌科

4) S. Yasumura : 山形大学医学部公衆衛生学

5) H. Haga：北海道医療大学看護学科

受付日：1998. 8. 10，採用日：1998.9. 16
るが，それによれば沖縄地方ではやや少ないという傾向 はあるものの，65歳以上の在宅高齢者における 1 年間で の転倒発生率はほぼ20\%前後となっている ${ }^{2)}$. 年齢が増 加するにつれ転倒の発生も増加し，さらに，それに伴っ て転倒による骨折発生率は上昇する ${ }^{3)}$. 従って高齢者に おいては骨折予防の第一歩は転倒予防であることは明白 である。

転倒は骨折（特に大腿骨頸部骨折）の重要なリスク・ ファクターであるが，転倒から骨折を予防する方法は大 きく別けて二つ考えられる.

一つは転倒をもたらす病因論的危険因子を改善するこ とである.これに関しては，高齢者における改善可能な 危険因子として，(1)視力障害，(2)鎮静剂や降圧剂などの 薬物服用による副作用，(3)筋肉低下に伴う身体活動性の 低下, そして, (4)家屋内外の物的環境の整備, などが重 視される. 特に視力障害や薬物副作用を積極的に改善す ることは大腿骨頸部骨折の介入効果の点からみても, 個 人レベルおよび社会的レベルのいずれにあってもその効 果は大きいと推定されている4). また転倒防止に係る俊 敏性やふらつきからの復元力などは下肢筋力の維持が重 
要であり ている6.

もう一つの骨折予防の方法は，装具を用いることによ り転倒による衝撃力（骨にかかる外力）を軽減消滅させ ることである，具体的には，大腿骨頸部骨折の予防を目 的として股関節周辺の骨格と筋肉を保護する装具が開発 されている．これらは，シリコンや硬質プラスチックを 用いる外力拡散型のものや，ゼリ一やエアバック方式に よる柔らかい素材による外力吸収型のものなどさまざま なタイプがある、いずれの装具も，楕円形状で大腿骨転 子部を被うため,下着に組み入れられているものである. これらの大腿骨頸部骨折を予防する装具を用いた介入研 究的取り組みは，欧米にあってはすでにいくつか知られ ている78). なかでも Lauritzen らのナーシングホームに おける装具を用いた介入研究》では，装具装着群での大 腿骨頸部・転子間骨折の発症率が非装着群に比べ約 $1 / 2$ に減少したことが報告され, 大きな関心を呼ぶに到った.

一方，このような装具を用いた臨床試験あるいは（施 設であれ在宅であれ）地域高齢者を対象とした介入研究 はまだまだ我が国では少ないのが現状である，本研究で は, 地域在宅の高齢者を対象とし, 大腿骨頸部骨折子防 装具を用いた場合の装着率の経時的変化や脱落の原因, さらには装着維持群と脱落群の差異などについて基礎的 分析を行なったので報告する.

\section{2. 対象と方法}

\section{2-1）対象}

東京都老人総合研究所では, 地域高齢者に関する老化 とそれに伴う機能低下や疾病の発生要因などの分析の他 に, 転倒や骨折の危険因子の分析やそれらの予防方法に ついてなど総合的な研究（TMIG-LISA）を高い精度を 維持しつつ長期綐断的に行なってきている もまたTMIG-LISA の一環として, 平成 9 年 9 月から平 成10年 3 月までの 6 力月間の追跡研究としてなされたも のである. 対象者は調查対象地域の 1 つである秋田県中 央部の山間部農村（ $\mathrm{N}$ 村）に居住する，70歳以上の在宅 高齢女性（356名）である.これら高龄女性のうち, 平 成 9 年 9 月の調査においいて, 過去 1 年間に転倒または転 倒・骨折を経験した，いわゆる転倒ハイリスク者は37名 (10.4\%) であった。この37名のなかで, 本研究の主旨 を充分に説明し, 参加協力の同意の得られた者20名に対 して追跡調查を行なった.この20名の平均年龄は75.4 2.55 歳 $(70 \sim 87$ 歳), 過去 1 年間の平均転倒回数は 2.55 回 ( 1 〜0回) であった.

2-2）方法

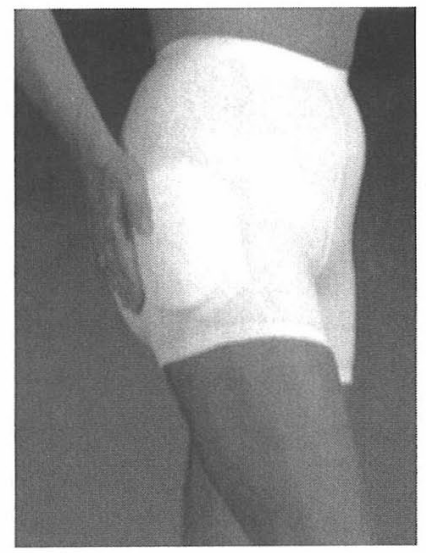

図 1 大腿骨頸部骨折予防装具

(Hip Protecter ${ }^{\circledR}$; Sahvatex). 両側大腿骨大転子部を保 護する目的で硬質ポリプロピレン製パットが入ってい る.

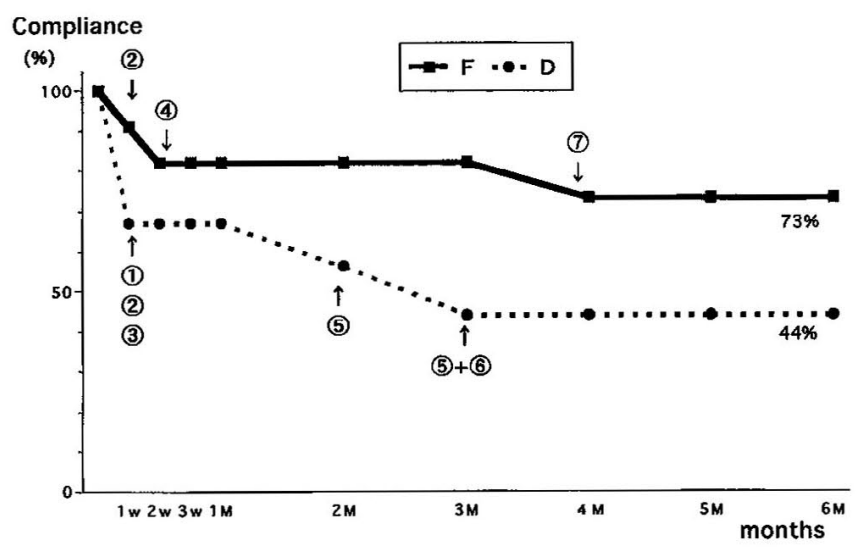

図 2 装着率 (Compliance) の推移（F：フィンランド 製，D：デンマーク製装具）丸囲み番号は表-1に記 載された脱落理由を示す。

同意の得られた 20 名に対し，大腿骨頸部骨折予防装具 を装着してもらった。用いた装具は 2 種類で，1つは硬 質ポリプロピレン製のパットの縫い込まれた Hip Protector $^{\circledR}$ (Denmark; Sahvatex; 図 1) であり，もう 1 つは軟質強化ゴム製のパットの縫い込まれた Safety Pants $^{\circledR}$ (Finland; Rounomo Oy) である.

各対象者にはサイズ，装着感などから自由にどちらか の装具を選択してもらい，対象者に（洗濯交換用も含め て）2個ずつを配布した. デンマーク製硬質パット装着 は 9 名であり，フィンランド製軟質パット装着は11名で あった。

対象者に対する装具装着の確認および脱落とその理由 については第 1 週，第 2 週，第 3 週， 1 カ月〜 6 カ月の 毎月の合計 9 回について, 訲問面接または電話による聞 
き取り調査でこれを確認した。

\section{3. 結 果}

装具装着20名のうち， 6 力月間全て指示通り装着して いた者は 12 名 $(60 \%)$ であった．装着率の推移を装具別 に示したものが図 2 である．デンマーク製硬質パットを 用いているのものは装着後 1 週間で $1 / 3$ が脱落した。 そ の後も少しずつ低下し最終的には $44 \%$ となった。一方， 軟質パットを用いたフィンランド製は第 1 週での脱落が 1名（9\%）であり，その後も比較的高い装着率を維持 し最終的に $73 \%$ 装着していた．両方のパットの装着率 について，6カ月目の装着率についてはカイ二乗検定に よって有意差は認められず $\left(\chi^{2}=1.650, p=0.200\right)$ ，また 装着率の推移については Kaplan-Meier 法を用いて計算 を行ない， logrank テストによって検定を行なったが， これについても有意な差は認められなかった $\left(\chi^{2}=1.800\right.$, $\mathrm{p}=0.183$ ).

脱落の理由を図 2 および表 1 に示す．早期の脱落者の 理由として，デンマーク製では「トイレ（排尿）に間に 合わない」が 2 例見られた。また「不適合あるいは違和 感」がデンマーク製およびフィンランド製に各々 1 名ず つ出現していた．特殊なケースとして，第 2 週目で脱落 した76歳女性（過去 1 年間の転倒回数 5 回）の例で,「自 分自身は装具装着を好ましく，また安心感もあったが， 主治医に見せたところ不要と言われた」ために，これを 中止した例が 1 例ある。.また 2 力月後， 3 力月後に脱落 した理由はいずれも「季節が寒くなり，下着の枚数が増 えて装着感が悪くなった」というものであった.

次に装具装着維持者と脱落者での差異を表-2に示す. パットの性状による統計的な有意差は認められなかっ た．年齢では脱落群が有意に高齢であった（78.5 vs 73.6 歳)。身体機能の面では脱落群の方が有意に握力が強く （23.0 vs 19.6），また問診票から得られた結果は，全て統 計的な有意差は認められなかった。

\section{4. 考察}

現在年間約 8 万人が受傷すると推定されている大腿骨 頸部骨折は，その予防の観点から装具の使用は今後の我 が国にあって極めて緊急性の高い問題であろう。装具に 関して落鍾式衝撃試験などにより，基礎的な生体力学的

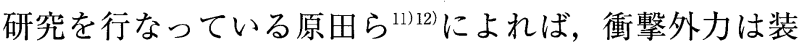
具着用により, ほぼ半減すると報告されており, 骨折予 防に確実な効果を上げることが期待されている，先の原 田ら ${ }^{13)}$ は大腿骨頸部骨折患者 25 名にデンマーク製 Hip Protector を24時間試着させ，その結果，楽に着用でき
表 1 脱落理由

\begin{tabular}{|c|c|}
\hline 早期 (第 1 週目) 脱落者： & \\
\hline 1）排尿時に脱ぐのが間に合わす尿が漏れる (D) & (87, 83 歳) \\
\hline 2) 不適合、違和感、鹃屈 $(D+F)$ & (79, 72 歳) \\
\hline 3）HP の上げ下げのための力がない (D) & (83 歳) \\
\hline 中・後期 (第 2 週目以降者)脱落者 & \\
\hline $\begin{array}{l}\text { 4）自分は安心感があったが, かかりつけの医者 } \\
\text { に不要と言われた }\end{array}$ & （76 歳） \\
\hline 5）寒くなり, 下着の枚数が増えたため & (74, 76 歳) \\
\hline $\begin{array}{l}\text { 6）胃切除の手術後のため，HP のゴム部分がき } \\
\text { つい }\end{array}$ & (76 歳) \\
\hline 7）長期入院 & (81 歳) \\
\hline
\end{tabular}

表 2 大腿骨䅡部骨折予防装具装着の (維持)継続群と脱 落群との差異

\begin{tabular}{|c|c|c|c|}
\hline & $\begin{array}{c}\text { 継続群 } \\
(\mathrm{N}=12)\end{array}$ & $\begin{array}{c}\text { 脱落群 } \\
(\mathrm{N}=8)\end{array}$ & 検定 \\
\hline $\begin{array}{l}\text { 装具性状 } \\
\text { 軟質 } \\
\text { 硬質 }\end{array}$ & $\begin{array}{l}8 / 11(73 \%) \\
4 / 9(44 \%)\end{array}$ & $\begin{array}{l}3 / 11(27 \%) \\
5 / 9(56 \%)\end{array}$ & \\
\hline $\begin{array}{l}\text { 年齢 }(\text { 歳 }) \\
\text { 身長 }(\mathrm{cm}) \\
\text { 体重 }(\mathrm{kg}) \\
\mathrm{BMI}\left(\mathrm{kg} / \mathrm{m}^{2}\right) \\
\text { 体脂肪率 }(\%) \\
\text { 握力 }(\mathrm{kg}) \\
\text { 開眼片足立 }(\text { 秒 }) \\
\text { 通常歩行速度 }(\mathrm{m} / \mathrm{sec}) \\
\text { 最大歩行速度 }(\mathrm{m} / \mathrm{sec}) \\
\text { 前腕骨密度 }\left(\mathrm{g} / \mathrm{cm}^{2}\right)\end{array}$ & $\begin{array}{c}73.6 \pm 3.6 \\
143.3 \pm 6.3 \\
50.1 \pm 9.6 \\
242.7 \pm 35.4 \\
30.0 \pm 7.0 \\
19.6 \pm 1.7 \\
13.4 \pm 12.0 \\
1.08 \pm 0.34 \\
1.51 \pm 0.37 \\
0.33 \pm 0.10\end{array}$ & $\begin{aligned} 78.5 & \pm 5.0 \\
145.2 & \pm 3.8 \\
48.5 & \pm 11.2 \\
229.6 & \pm 48.7 \\
25.3 & \pm 6.9 \\
23.0 & \pm 2.2 \\
15.2 & \pm 23.0 \\
0.94 & \pm 0.29 \\
1.72 & \pm 0.33 \\
0.29 & \pm 0.05\end{aligned}$ & $\begin{array}{l}* \\
\text { NS } \\
\text { NS } \\
\text { NS } \\
\text { NS } \\
* * \\
\text { NS } \\
\text { NS } \\
\text { NS } \\
\text { NS }\end{array}$ \\
\hline $\begin{array}{l}\text { 健康度自己評価 } \\
\text { 健康 +まあ健康 (\%) } \\
\text { 体の痛みや不具合 } \\
\text { 古h }\end{array}$ & 83.3 & 75.0 & NS \\
\hline $\begin{array}{l}\text { 過去 } 1 \text { 年間の平均転倒回数 } \\
\text { 骨折の有無 }\end{array}$ & $\begin{array}{c}54.2 \\
2.42\end{array}$ & $\begin{array}{c}56.3 \\
2.75\end{array}$ & $\begin{array}{l}\text { NS } \\
\text { NS }\end{array}$ \\
\hline $\begin{array}{l}\text { あり (\%) } \\
\text { 総合的 } \mathrm{ADL}(7 \text { 項目) } \\
\text { 低下あり }(\%) \\
\text { 老研式活動能力 (13 点) } \\
\text { 平均点 }\end{array}$ & 16.7 & 25.0 & $\begin{array}{l}\text { NS } \\
\text { NS }\end{array}$ \\
\hline
\end{tabular}

$*) \mathrm{p}<0.05, * *) \mathrm{p}<0.01$, NS) no significance

た者 $44 \%$ 含め $72 \%$ が装具着用を許容したが，拒否も含 め28\%は受容不良であったと報告している。

今回我々は，地域在宅高齢者を対象として，装具の装 着率の推移や脱落の理由，脱落群の特性などを明らかに する目的で，6力月間の追跡研究を行なった。まず，装 着率についてみると，軟質（強化）ゴムパットを用いた フィンランド製装具の装着率は高く，6カ月を通じても 70\%以上を維持していた。一方，硬質ポリプロピレン製 パットを用いたデンマーク製装具は，既に第 1 週で $1 / 3$ 
が脱落し，最終装着率は44\%と劣っていた，恐らく，硬 質パットの方が，適合感が劣るためと考えられるが，両 者に有意差はなく, 第 2 週以降装具装着に慣れてくると， 硬質パットであっても比較的高い装着の維持率が期待さ れると考えられる。また注意しなければならない点とし て, 装着率の良否もさることながら，実際の転倒による 衝撃外力を減弱させ, 大腿骨頸部骨折を予防する確率に 関する成果が公表されているデンマーク製硬質パットは その信頼性が高い。一方，軟質パットのデー夕はまだ充 分とはいえない欠点が残っている.

次に脱落の理由であるが，これは早期（第 1 週目）の 脱落理由と, 中・長期 (1 力月以降) でのそれとは若干 異なっている. すなわち, 早期脱落理由としては「不適 合，違和感」の他に，特にデンマーク製の硬質パットの 装具で「排尿時に間に合わない（尿漏れ）」が主要な原因 となっていることが注目される。このような高齢者の場 合には，比較的ゆったりとしたフィンランド製の軟質 パットの装具の方が適していると推定される.

脱落理由の 1 つに「自分自身は装具着用で安心してい たが, 主治医に不要と言われた」という症例が見られた。 大変残念なケースとも考えられ, 今後, 医師の側にも転 倒・骨折予防のための具体的方策について配慮が望まれ る.

1〜2 カ月後に脱落した理由では「寒くなり下着の枚 数が増えたためにパット入り装具が窮屈となった」とい うのが 2 例見受けられた。これは恐らく秋田地方という 寒冷な地域特性でもあると考えられるが, 解決方法とし てサイズを一回り大きくするなどの手段により, 装着維 持は可能な例であると考えられた。

脱落理由から見る限り, 装着率の改善可能な理由がほ とんどを占めている.すなわち装具の種類の変更, サイ ズの変更, 医師の理解などにより, 今回の対象者では装 着率にかなりの改善が見込まれる。従って, 装着にあたっ ては，転倒や骨折に関する充分な説明と予防装具のきめ 細かな装着の指導により，かなり高い装着率の維持が期 待出来るものと考えられた。

大腿骨頸部骨折予防装具の装着についてこれを 6 力月 間維持しえた者（12名）と途中で脱落した者（8名）の 両群の特性についてみると, 年齢は脱落群で有意に高く なっていた（78.5 vs 73.6歳）。これは特に早期に脱落し た83歳女性と87歳女性によることが大きい。この両者は デンマーク製装具であり, 脱落理由はいずれも「排尿時 に間に合わない」というものであった。

両群に有意な差のみられた身体機能は, 握力のみであ り，脱落群でむしろ高かった(23.0 vs 19.6kg)。これが，
偶然的な理由か，あるいは筋力があって比較的元気な者 （すなわち総合的 ADL 低下の割合がゼロであった者） は，むしろ身体活動に窮屈感を感じて脱いでしまったの かは不明である。

今回調查した身体機能の大部分や，あるいは 1 年間の 転倒回数, 老研式活動能力平均得点など, 両群にほとん どに有意差はみられなかった.いずれにせよ，今回のわ ずか20名を対象とした追跡研究では, 維持群と脱落群と の間で明瞭で説明可能な差異は見い出せなかったと言え る. 今回の研究に用いた大腿骨頸部骨折予防装具は, 現 時点では比較的高価 ( 1 個約 8 千円から 1 万円) である. 1 人の対象者には洗濯交換のために最低 2 個ずつの配布 が必要であることや，時節によってはサイズも変えなけ ればならないなど, 相当な経費負担も必要である.ささら に直接海外発注して取り寄せなければならないなど, 現 状では一般住民が入手するにはかなりの困難が予想され る. 今後, 研究の面では対象人数を増やして追跡期間も 延長した大規模介入研究を行なうとともに，このような 予防装具が一般化してゆく上で，人々に予防装具の重要 性を理解して頂くと同時に, 我が国でも廉価で入手しゃ すい製品の普及することが望まれる.

\section{文献}

1) Melton LJ III : Osteoporosis: Etiology, Diagnosis, and Management. pp111-131, Ravaen Press, New York, 1988.

2) 平成 7 年度一平成 8 年度科学研究費補助金研究成果報告 書：地域の高齢者における転倒・骨折に関する総合的研 究, 1997, p163.

3) Suzuki T, Yoshida H, Ishizaki T, Yukawa H, Watanabe $\mathrm{S}$, Kumagai S: Osteoporotic fractures by falls among the elderly. Facts, Research and Intervention In Geriatrics (Vellas B et al), pp29-42, Serdi, Paris, 1997.

4) Cummings SR: Treatable and untreatable risk factors for hip fracture. Bone 1996 ; 18: 165S-167S.

5) Hayashi $Y:$ Osteoporosis in the elderly. The Olympic book of sports medicine (Ditix A et al ed), p355-359, Black well Sci Pub, Oxford, 1988.

6) Lipsitz LA, Nakajima I, Gegnon M, Hirayama T, Connelly C, Izumo $\mathrm{H}$ : Muscle strength and fall rates among residents of Japanese and American nursing homes-an international cross-cultural study. J Am Geriatr Soc $1994 ; 42: 953-959$.

7) Lauritzen JB, Petersen MM, Lund B : Effect of external hip protectors on hip fractures. Lancet 1993;341:1113.

8) Myers AH, Michelson JD, Natta MV, Cox Q, Jinnah R: Prevention of hip fractures in the elderly-Receptivity to 
protective garments. Arch Gerontol Geriat 1995;21: 179-189.

9) Shibata H, Suzuki T, Shimonaka Y, Koyano W : Launch of a new logitudinal interdisciplinary study on aging by Tokyo Metropolitan Institute of Gerontology (TMIGLISA). Facts and Research in Gerontology 1993; 7 : 177-184.
10) Shibata H, Suzuki T, Shimonaka $Y$ (Eds) : Longitudinal Interdisciplinary Study on Aging. pp190, Serdi Publisher, Paris, 1997.

11）原田 敦, 奥泉宏康：大腿骨頸部骨折とヒッププロテク ターの予防効果. Geriat Med 1996;34:1668一1670.

12）原田 敦, 奥泉宏康：ヒッププロテクターの効果とコン プライアンスの検討. 日老医誌（抄録集）， $34: 78$.

Abstract

Compliance in Use of External Protectors for Hip Fractures among the Community Elderly in Japan.

Takao Suzuki ${ }^{1}$, Hideyo Yoshida ${ }^{1)}$, Tatsuro Ishizaki ${ }^{1)}$, Harumi Yukawa ${ }^{1)}$, Shuichiro Watanabe ${ }^{2)}$, Shu Kumagai ${ }^{2)}$, Shoji Shinkai ${ }^{2)}$, Hiroshi Shibata ${ }^{2)}$,

Tetsuro Nakamura ${ }^{3)}$, Seiji Yasumura ${ }^{4)}$ and Hiroshi Haga ${ }^{5)}$

To protect femoral neck fractures which are the most serious complication of osteoporosis and are increasing in frequency in Japan, an external hip protector (EHP) fixed in special underwear has been proven to absorb a direct impact to the greater trochanter during a fall from standing height.

In this study, we investigated compliance concerning the use of EHPs, for six months using two types of EHP, i.e., hard pad type (Hip Protector ${ }^{\circledR}$, Sahvatex) from Denmark (Fig. 1) and soft pad type (Safety Pants ${ }^{\circledR}$, Rounomo Oy) from Finland.

The subjects were 20 elderly women aged 70 years or more who had at least one experience of falling within the year preceding the baseline survey in September of 1997.

The compliance rate is shown in Fig. 2. Though the soft type EHP had relatively better compliance than the hard type EHP, there was no significant difference between them. The main reason for early dropout (one or two weeks after baseline) was "difficulty to remove especially with regard to using the toilet". The main reason for later dropout was "too tight to wear in winter". There were no significant differences with regard to anthropometric measurements, physical activity, ADL, and rate of falls between compliers and dropouts except age (73.6 vs 78.5 yrs).

Sufficient explanation at baseline and generatively good motivation for wearing the EHP will maintain a high compliance which may result in the effective prevention of hip fractures among the community elderly.

Key words : External protector for hip fractures, Compliance, Community elderly, Fall (Jpn J Geriat $1999 ; 36: 40-44$ )

1) Department of Epidemiology, and 2) Department of Community Health, Tokyo Metropolitan Institute of Gerontology

3) Tokyo Metropolitan Geriatric Hospital

4) Department of Public Health, Yamagata University School of Medicine

5) Division of Public Health, School of Nursing and Social service, Health Science University of Hokkaido 